\title{
GOVERNMENT EFFORTS TO IMPLEMENT THE GREEN BUILDINGS MARKET IN DKI JAKARTA
}

\author{
Hendi Prihanto* \\ Department of Accounting, Faculty of Economics \\ Universitas Prof. Dr. Moestopo (Beragama) \\ *Correspondence: hendiprihanto@dsn.moestopo.ac.id
}

\section{ARTICLE INFO}

\section{Article History:}

received: $07 / 09 / 2021$

revised: $20 / 10 / 2021$

accepted: 31/10/2021

\section{Keywords:}

intellectual capital, governance, green

building, market, DKI Jakarta

DOI:

https://doi.org/10.32509/mirshus.v1i2.19

\begin{abstract}
Green buildings are very important and become a necessity that is environmentally friendly, this research was conducted to analyze the government's efforts to implement the market with buildings through aspects that influence it such as intellectual capital (human capital, organizational capital, customer capital) and governance. Sampling was carried out randomly through the distribution of questionnaires carried out in a number of markets spread across the DKI Jakarta area as a population, so that the results of research observations obtained a number of 170 samples filled in by market managers from different regions. Multiple linear regression and statistical hypothesis testing $t$ are analyzes used to test hypotheses with data analysis tools using SPSS software. The research concludes that the dimensions of intellectual capital, namely human capital and organizational capital, have a significant positive effect, while customer capital and governance do not have a significant effect on market implementation with green buildings. The limitation of the study is that the sample used at random has not been able to conclude the overall results, In addition, the questionnaire submitted has the potential to be inconsistent with existing facts because of the possibility of subjectivity that can occur.
\end{abstract}

\section{INTRODUCTION}

Green buildings can be interpreted as a condition in which buildings used in activities are built using environmentally friendly, comfortable and safe assumptions for users based on ecological principles
(Glavinich, 2008) which minimizes the negative impact. The Indonesian government itself is currently trying to implement green buildings in stages and regulate every spatial plan that is made, in addition to corporations also participating in 
designing and implementing the use of green buildings for sustainable business activities. Most buildings in Indonesia, especially DKI Jakarta, have not implemented the green building concept, so many often experience fires and other adverse events that result in damage to the surrounding environment. Green buildings are very important to implement because the concept contains benefits, for example in 2019 there were fires in a number of market locations due to the inappropriateness of buildings used as places for community activities (Valenta, 2019) caused by electrical short circuits, garbage disposal, lack of routine maintenance and so on coupled with unbalanced density in the location area. This incident was caused by the fact that buildings with traditional concepts have not been converted into environmentally friendly buildings, so they are prone to dangers that threaten the lives of people who use the facilities.

Green buildings can be realized with the intellectual capital owned by the organization, intellectual capital is also very important role in the effectiveness of organizational management, then supported by a good and positive human resource management system capable of producing high performance (Kianto et al., 2017; Sokolov \& Zavyalova, 2018). Intellectual capital can be maximally empowered by providing knowledge that is shared with work equipment, Furthermore, it has an effective and positive effect on the three components of intellectual capital, namely : human capital, structural capital and relational capital that lead to every dimension of intellectual capital to take action for innovation (Allameh, 2017). Innovation towards infrastructure such as markets with the concept of green buildings used by the public, can be realized through good governance. Governance also has a key role that determines the quality of service performance to the community (Mahrani \&
Soewarno, 2018), because good service does not lie in public satisfaction, but furthermore, the better the future service (Ndraha, 2011). Some researchers on governance (Abousamak \& Shahwan, 2018; Shahwan \& Fathalla, 2020) observing and analyzing poor governance that causes problems in organizational practices such as low quality of work, fraudulent behavior, implementation of risk management and so on.

This research is important to do in order to improve government services to the community, as well as testing the accuracy of the predictor research variables, because based on the researcher's search there has been no specific literature that examines and analyzes the effectiveness of the application of green buildings to the public, especially those related to market objects with green buildings. For this reason, this study aims to analyze the influence and role of intellectual capital on efforts to implement green buildings in a number of markets in the DKI Jakarta area. The research contributes to the theoretical aspects that build literacy in the successful implementation of environmentally friendly green buildings in Indonesia, while the practical aspects provide solutions for the government and related parties towards the creation of maximum efficient and effective green buildings by providing guarantees for the safety and comfort of public activities.

\section{METHOD}

The research was conducted on a number of Pasar Jaya located in DKI Jakarta province from January - May 2021 with indications as an object that the market is currently trying to develop, and development towards a green market with building criteria as referred to in the theoretical aspect or government regulations. A number of respondents were taken randomly to fill out the questionnaire with the intention of avoiding partiality, the 
sample selected was market managers starting from the Head of the Market to the staff who helped in managing the market location. The total questionnaires obtained were 197 questionnaires from observations that could not be used due to problems with completeness and accuracy when filling them out, so that after the final selection, 170 samples were obtained which were suitable for use in data processing.

\section{Measurement}

Measurement of the questionnaire using an interval scale of 1) strongly disagree, 2) disagree, 3) disagree, 4) agree, 5) strongly agree, 6) strongly agree, which is a modification of the Likert scale intended for questionnaire answers. The green building variable is measured by Permen PU
RI NO: 02/PRT/M/2015 (programming stage, technical planning stage, construction implementation stage, utilization stage and demolition stage). Intellectual Capital Variable (Yu et al., 2017) consists of: 1) Human Capital (skills, beliefs, expectations, values, subjective experience); 2) Organizational Capital (collaboration, leadership, knowledge, product innovation, system innovation) and 3) Customer capital (relationships with: customers, suppliers, investors, community). Governance Variables (Wajeeh, 2012) measured by: discipline, transparency, independence, accountability, responsibility, justice. The research hypothesis that is built based on the literature used is.

Table 1. Research Hypothesis

\begin{tabular}{ll}
\hline Hypotesis & \multicolumn{1}{c}{ Description } \\
\hline $\mathrm{H} 1$ & Human capital has a positive effect on the implementation of green buildings \\
$\mathrm{H} 2$ & Organizational capital has a positive effect on the implementation of green buildings \\
$\mathrm{H} 3$ & Customer capital has a positive effect on the implementation of green buildings \\
$\mathrm{H} 4$ & Governance has a positive effect on the implementation of green buildings \\
\hline
\end{tabular}

\section{DISCUSSION}

The descriptive statistics of the research conducted stated that the mean value was greater than the standard deviation, which means that the composition of the research data was feasible. To see the results of the feasibility of testing the instrument and research hypotheses can be presented in tables 3.1 and 3.2 below.

Table 2. Validity and Reliability Test

\begin{tabular}{ccccc}
\hline Variable & Validity & Noted & Reliability & Noted \\
BH & $0.518-0.789$ & Valid & 0.955 & Reliabel \\
MM & $0.489-0.679$ & Valid & 0,915 & Reliabel \\
MO & $0.564-0.743$ & Valid & 0,932 & Reliabel \\
MP & $0.487-0.635$ & Valid & 0,853 & Reliabel \\
TK & $0.525-0.723$ & Valid & 0.952 & Reliabel \\
\hline
\end{tabular}

Noted:

1 Validity All variables have a value of $r$ count $>r$ table (0.159).

2 Reliability of all variables has a value of $>0.70$

Table 3. Hypothesis Test

\begin{tabular}{|c|c|c|c|c|c|}
\hline \multicolumn{6}{|c|}{$\mathrm{BH}=3.762 \mathrm{a}+0.583 \mathrm{MM}_{1}+0.711 \mathrm{MO}_{2}+0.165 \mathrm{MP}_{3}+0.080 \mathrm{TK}_{4}+\mathrm{e}$} \\
\hline Variable & Predictive & Koef. & P-Val. & Sig. & Noted \\
\hline $\mathrm{MM} \rightarrow \mathrm{BH}$ & $\mathrm{H} 1(+)$ & 4.721 & 0.000 & Sig. ${ }^{* * * *}$ & H1 Accepted \\
\hline $\mathrm{MO} \rightarrow \mathrm{BH}$ & $\mathrm{H} 2(+)$ & 4.388 & 0.000 & Sig. $* * * *$ & H2 Accepted \\
\hline $\mathrm{MP} \rightarrow \mathrm{BH}$ & $\mathrm{H} 3(+)$ & 0.705 & 0.428 & Tidak sig. & H3 Rejected \\
\hline $\mathrm{TK} \rightarrow \mathrm{BH}$ & $\mathrm{H} 4(+)$ & 0.975 & 0.331 & Tidak sig & H4 Rejected \\
\hline
\end{tabular}




\section{Effects of Human Capital and Green Buildings Implementation}

The results of testing the research hypothesis state that the dimensions of intellectual capital of human capital have a positive effect on the application of markets with green buildings, thus $\mathrm{H} 1$ is accepted. The results are in line with research which states that human capital will affect individual performance and ultimately affect the organization (Helmiatin, 2015) which encourages the implementation of green buildings in the market. Previous research (Astuti \& Datrini, 2021; Huang \& Kung, 2011) states that intellectual capital based on knowledge of the green environment has the competence and commitment to activities related to innovation and competitiveness which requires good and positive management of resources (Sokolov \& Zavyalova, 2018), For this reason, human intellectual capital serves as the main function of improving the performance of environmentally friendly green innovations.

Human capital has the main element in moving the next instrument used in taking action, because human capital is based on education, thinking skills, reasoning and feelings that determine whether or not the behavior is ethical or not (Prihanto, 2018) on the basis of careful consideration. The ability to think accompanied by knowledge gives government officials the strength and ability to understand the existing market conditions and the appropriate needs to be done in providing shopping facilities to the public that are comfortable, safe and friendly to the environment as a public service agency. The concept of a market with green buildings requires a lot of understanding from every manager in charge of market management at various levels (top to bottom), because the concept provides its own consequences for its users with better added value in the long term than traditional markets which have low added value. There are not many markets with green buildings in Indonesia, especially DKI Jakarta, its implementation must begin with the provision of understanding, education, and training on management resources so that they can run effectively and finally become part of the community culture. According to a study on the implementation of green buildings in Singapore, there is an additional cost of around $\$ \$ 60$, but every month you can save up to $\mathrm{S} \$ 156$ because green buildings have a higher value (Elena, 2019). Thus the green building concept is able to reduce costs and make it more efficient in managing finances.

\section{Effects of Organizational Capital and Green Buildings Implementation}

The results of the statistical test of the study stated that organizational capital had a positive effect on market implementation with green buildings so that $\mathrm{H} 3$ was accepted. The results are also in line with the research references used previously that organizations are facilities and infrastructure for employees to create optimum performance, including the organization's ability to reach the market, organizational structure, patents, trademarks, and all organizational capabilities to support employee productivity (Bontis \& Fitz-enz, 2002; Ramadan et al., 2017). Organizational capital provides support for the empowerment of human capital to go through a transformation process through the knowledge of values created. The goal achieved is to have the ability to improve 
individual employee performance which makes performance effective, with the availability of infrastructure and supporting financing (Christa, 2013; Delgado-Verde et al., 2014) such as green buildings that are ecological.

Institutional organizational capital provides guarantees after human capital is met appropriately, then with the organization it becomes a place that makes it possible for humans in the shelter to start and carry out their activities through a series of routine work and innovations. This capital provides the substance that establishes communication and relationships between humans in it (Inkinen, 2015) to start and contribute. Markets with green buildings can be implemented properly by being facilitated by organizations that are responsible for professionally handling, managing, maintaining and developing properly according to feasibility standards. Financial needs that are not cheap become the authority and obligation of the organization to provide financing, both at the top level as the financial holder and at the bottom as the executor. Budget problems are always an obstacle, synergies are formed in implementing green market buildings, providing coordination and command lines between relevant management in their implementation in accordance with land use in the DKI Jakarta area along with the completeness, needs and risk mitigation carried out. The application of the market with green building criteria has a cost that is quite expensive, because the concept of the building has completeness and is equipped with infrastructure that prevents various dangerous things such as electrical short circuits, good garbage disposal channels, supporting facilities for accidents at work, cleanliness and other things to avoid environmental damage. For this reason, this kind of market building requires a fairly large investment from all parties, especially the government as an agent, but has a number of additional benefits in the future that are profitable. DKI Jakarta's green building concept has been initiated in the Grand Design Green Building (2016), based on the Grand Design of the Green Building, in 2030 Jakarta will reduce energy consumption, water consumption and reduce greenhouse gas emissions by 30 percent respectively. prevent negative impacts and improve the health of the surrounding environment that can be applied to settlements or residential residents, which is a form of concern for the environment (Rianti, 2020).

\section{Effect of Customer Capital and Green Buildings Implementation}

The results of research data processing state that customer capital does not have a positive effect on the application of green buildings, so $\mathrm{H} 3$ is rejected. The results of the study are not in line with previous research that it is expected that customer capital oriented to green knowledge will have an effect on increasing human resources (Yong et al., 2019) which will affect the organization's performance in building green buildings. Customer capital with green knowledge should be a medium that strengthens the relationship of stakeholders in the organization with environmental management, as well as using the market as a place for the organization's operations to maintain the image and reputation of the company's environment and social relations. (Lopez-Gamero et al., 2011). Consumer satisfaction is achieved if the intensity of the government can handle good market management, and is able to create good relationships by achieving added value so that it directly improves performance (Hermawan et al., 2015) in the form of providing environmentally friendly green buildings to support public business activities.

Customer capital can also be a measurement of the organization's ability to 
identify the needs, and desires of partners so that the relationship is well established with outside parties such as government, market, suppliers and customers and other stakeholders. The current needs of the community in the economy are facilities that support comfortable and safe activities, because the fulfillment of the current needs for public activity facilities cannot be fully met. Dissatisfaction with the availability of facilities and infrastructure expected by the community, giving feedback in the form of an attitude of disappointment and indifference to the community which ultimately makes them not care and support the programs run by the government. Customer capital will be more effectively obtained with full support from stakeholders, the public who provide full support to government organizations in implementing various policies and programs by helping to achieve them (Dowling \& Pfeffer, 1975). The phenomenon that occurs in Indonesian society, most people do not understand and know about the importance of the concept of green buildings in everyday life which helps provide sustainability, not only in their business, commercial and health activities but also in the life around them. Based on new concepts designed for buildings that have already begun to be implemented, including the construction of the Ministry of Public Works and Housing, a number of newly designed traditional markets, energy-efficient flats, and university buildings (Laucereno, 2021).

\section{Effect of Governance and Green Buildings Implementation}

The results of research data processing state that governance does not have a positive effect on the implementation of green market buildings, so H3 fails to be accepted. The results of the study are also not in line with the previous researcher's statement, that the existence of good governance in the organization will have a positive impact on efforts for improvements with awareness of implementing green buildings (Hsieh et al., 2020) which of course is also supported by positive environmental performance (Freedman et al., 2014). The governance carried out aims to guarantee the regularity of the implementation of public services to the public who act in the interests of the community (Mahrani \& Soewarno, 2018), because the government as an agent mandated by the people to act on behalf of the people (Jensen \& Meckling, 1976). Through good governance provide control, prevent, and minimize the occurrence of irregularities by agents who are mandated (Abousamak \& Shahwan, 2018; Platt \& Platt, 2012; Prihanto, 2020) by the people to serve them.

The governance carried out in the context of market management in the DKI Jakarta area and other regions in Indonesia, on average, is still based on traditional management principles that put forward a distinctive style of self-taught and modestbased management based on knowledge without the concept of a green environment. Some phenomena of weak governance can be seen in the market environment that is slum, dirty, unhygienic, jammed, not well organized because many traders sell in inappropriate places and so on as a result of the government being unable to control activities in the market. The lack of success of the governance applied to realize the ideal market green building, is because the knowledge capital of the customer as one of the forming intellectual capital in the market community is less able to be formed and of good quality. The knowledge and lack of skills possessed by the actors in the market proves the difficulty of forming the green market building concept that is planned because of low understanding. In the form of implementation of governance, the Government is currently trying to issue regulations related to environmentally friendly development, namely PUPR Ministerial Regulation Number 9 of 2021 
concerning Guidelines for the Implementation of Sustainable Construction and PUPR Ministerial Regulation Number 21 concerning Performance Assessment of Green Buildings which is also the implementation of the Job Creation Act (Laucereno, 2021).

\section{CONCLUSION}

The results of the study indicate that human and organizational intellectual capital has a positive and significant effect, while customer capital and governance have no significant effect on efforts to implement markets with environmentally friendly green buildings. The problem of the unsuccessful implementation of the market with green buildings is due to the lack of knowledge from the stakeholders who do not realize the importance of the market concept with green buildings that are environmentally friendly, the budget allocation is still not optimal for development, commitment to good and sustainable management of environmentally friendly markets. Research using perception has a lack of commitment and is consistent with the answers obtained, besides the lack of samples used in this study makes the conclusions from the results of data processing less representative of the actual situation. For this reason, it is recommended that future research using surveys with a larger sample size as well as provide confirmation to the parties related to market management. The research results obtained can be used as a reference, especially for the government in conducting environmentally friendly market-based management as the location of the main community's economic activities. Customer capital that has not been effectively empowered and less than optimal governance has become an important supporter in the effort to achieve the expected green building market. The problems faced by the community and the government provide opportunities in the theoretical aspect that the services provided by the government have not been able to achieve better conditions in the future, but are still incidental in nature which can change quality at any time.

\section{REFERENCES}

Abousamak, A., \& Shahwan, T. (2018). Governance mechanisms and earnings managementpractices: evidence from Egypt. International Journal of Corporate Governance, 9(3), 316-346.

Allameh, S. M. (2017). Antecedents and consequences of intellectual capital The role of social capital, knowledge sharing. Journal of Intellectual Capital, 19(5). https://doi.org/10.1108/JIC05-2017-0068

Astuti, P. D., \& Datrini, L. K. (2021). Green competitive advantage: Examining the role of environmental consciousness and green intellectual capital. Management Science Letters, January, 1141-1152. https://doi.org/10.5267/j.msl.2020.1 1.025

Bontis, N., \& Fitz-enz, J. (2002). Intellectual capital ROI: A causal map of human capital antecedents and consequents. Journal of Intellectual Capital, 3(3), 223-247.

https://doi.org/10.1108/146919302 10435589

Christa, U. R. (2013). Peran human capital dan structural capital dalam meningkatkan kinerja organisasi (suatu kajian konseptual). Jurnal Sains Manajemen, 1(1), 2302-1411.

Delgado-Verde, M., Amores-Salvadó, J., Castro, G. M.-D., \& Navas-López, J. E. (2014). Green intellectual capital and environmental product innovation: the mediating role of green social capital. Knowledge Management Research \& Practice, 12(3), 261-275.

Dowling, J., \& Pfeffer, J. (1975). Organizational Legitimacy: Social Values and Organizational Behavior. 
Pacific Sociological Association, 18(1), 122-136.

Elena, M. (2019). Baru Jakarta dan Bandung yang Punya Aturan Bangunan Hijau. Bisnis.Com.

Freedman, Martin, Jaggi, \& Bikki. (2014). Accounting for the Environment: More Talk and Little Progress. iii. https://doi.org/10.1108/s1479359820140000005009

Glavinich, T. E. (2008). Contractor's Guide to Green Building Construction: Management, Project Delivery, Documentation, and Risk Reduction.

Helmiatin. (2015). Optimalisasi Peran Modal Intelektual Terhadap Kinerja Karyawan. Journal of Chemical Information and Modeling, 53(9), 1689-1699.

Hermawan, S., Hariyanto, W., \& Sumartik. (2015). Integrasi Intellectual Capital dan Knowledge Management serta Dampaknya pada Kinerja Bisnis Perusahaan Farmasi. Jurnal Akuntansi Multiparadigma, $\quad 6(3), \quad 385-398$. https://doi.org/10.18202/jamal.2015 .12 .6031

Hsieh, H., Claresta, V., Minh, T., \& Bui, N. (2020). Green Building, Cost of Equity Capital and Corporate Governance: Evidence from US Real Estate Investment Trusts. Sustainability, 12(3680).

Huang, C.-L., \& Kung, F.-H. (2011). Environmental consciousness and intellectual capital management: Evidence from Taiwan's manufacturing industry Cheng-Li. Management Decision, 49(9), 14051425.

Inkinen, H. (2015). Review of empirical research on intellectual capital and firm performance. Journal of Intellectual Capital, 16(3), 518-565.

Jensen, M. C., \& Meckling, W. H. (1976). Theory of The Firm: Managerial Behavior, Agency Cost And Owneship Structure. Journal of Financial Economics 3, 3, 305-360.
Kianto, A., Saenz, J., \& Aramburu, N. (2017). Knowledge-based human resource management practices, intellectual capital and innovation. Journal of Business Research, 81.

Laucereno, S. F. (2021, October). Tahun 2030 Bangunan di DKI Harus Ramah Lingkungan, Kayak Gimana Tuh? DetikFinance.

https://finance.detik.com/properti/d -5752515/tahun-2030-bangunan-didki-harus-ramah-lingkungan-kayakgimana-tuh

Lopez-Gamero, M. D., Molina-Azorín, J. F., \& Claver-Cortes, E. (2011). Environmental Management and a Whole Framework. International Journal of Tourism Researcof Tourism Researc, 13(September 2010), 141163.

Mahrani, M., \& Soewarno, N. (2018). The effect of good corporate governance mechanism and corporate social responsibility on financial performance with earnings management as mediating variable. Asian Journal of Accounting Research, 3(1), 41-60. https://doi.org/10.1108/AJAR-062018-0008

Ndraha, T. (2011). Kybernologi Ilmu Pemerintahan Baru. Rineka Cipta.

Platt, H., \& Platt, M. (2012). Corporate board attributes and bankruptcy. Journal of BusinessResearch, 65(8), 1139-1143.

Prihanto, H. (2018). Etika Bisnis dan Profesi: Sebuah Pencarian. Rajawali Pers.

Prihanto, H. (2020). Manajemen Pengetahuan Memoderasi Pengaruh Budaya Organisasi, Kepemimpinan Etis, Kode Etik dan Sistem Pengendalian Internal Pemerintah Terhadap Pencegahan Korupsi. Trisakti.

Ramadan, B. M., Dahiyat, S. E., Bontis, N., \& Al-dalahmeh, M. A. (2017). Intellectual capital , knowledge management and social capital within the ICT sector in Jordan. Journal of Intellectual Capital, 18(2). 
Rianti, E. (2020, September). Pemprov DKI Dorong Implementasi Konsep Bangunan Gedung Hijau. REPUBLIKA.CO.ID.

https://www.republika.co.id/berita/ qgwc0h457/pemprov-dki-dorongimplementasi-konsep-bangunangedung-hijau

Shahwan, T. M., \& Fathalla, M. M. (2020). The mediating role of intellectual capital in corporate governance and the corporate performance relationship. International Journal of Ethics and Systems, 1998. https://doi.org/10.1108/IJOES-032020-0022

Sokolov, D., \& Zavyalova, E. (2018). Human resource management systems and intellectual capital : is the relationship universal in knowledge-intensive firms? International Journal of Manpower.

https://doi.org/10.1108/IJM-112018-0372

Valenta, E. (2019, March). 200 pasar tradisional terbakar sepanjang 2019. Lokadata.

https://lokadata.id/artikel/200pasar-tradisional-terbakarsepanjang-2019

Wajeeh, I. A. (2012). Strategic corporate governance for sustainable mutual development. International Journal of Law and Management, 54(3), 197208.

https://doi.org/10.1108/175424312 11228593

Yong, J. Y., Yusliza, M. Y., Ramayah, T., \& Fawehinmi, O. (2019). Nexus between green intellectual capital and green human resource management. Journal of Cleaner Production, 215, 364-374. https://doi.org/10.1016/j.jclepro.201 8.12.306

Yu, A., Garcia-Lorenzo, L., \& Kourti, T. (2017). The role of intellectual capital reporting (ICR) in organisational transformation: a discursive practice perspective. Critical Perspectives in Accounting, 45(1), 48-62. 